This is the 'post-print' version (accepted following the referee process) of this paper in accordance with the Green Access standard for this journal

Oxbrough, A. G., Gittings T., O'Halloran J., et al. 2006. The initial effects of afforestation on ground-dwelling spider fauna among several habitat types. Forest Ecology and Management: 237, 478-491.

\title{
The initial effects of afforestation on the ground-dwelling spider fauna of Irish peatlands and grasslands
}

Anne G. Oxbrough*, Tom Gittings, John O’Halloran, Paul S. Giller, Tom C. Kelly

Department of Zoology, Ecology and Plant Science, Cooperage Building, University College Cork, Distillery Fields, North Mall, Cork, Ireland

*Corresponding author. Tel: +353214904677; fax: +353214904664; E-mail address: aoxbrough@hotmail.com 


\section{Abstract}

Across Europe, the majority of afforestation is carried out on former agricultural land. Given this current planting trend it is important to assess the impact that afforestation will have on the flora and fauna of habitats typically used for afforestation. The study aim was to investigate the initial effects of afforestation (5 years after planting) on the ground dwelling spider fauna within three habitats (peatlands, improved grasslands and wet grasslands) in Ireland. A paired sampling approach was used where 24 pairs of unplanted and planted sites (eight within each habitat type) were matched for habitat, vegetation type, soil properties, and geographical location. The planted sites were comprised of five year old stands of Sitka spruce (Picea sitchensis). Within each habitat pitfall traps were established in areas of vegetation cover representative of the site as a whole, as well as in supplementary features which may also contribute to the biodiversity of a site, for instance in hedgerows, wet flushes, and the edges of ditches or streams.

During the study 33,157 spiders were collected in 189 species and 18 families. Forty species sampled were associated with open habitats whereas 15 species were associated with forested habitats; and, 54 species were associated with wet habitats whereas two species were associated with dry habitats. Across the habitats fewer wet-associated species and fewer rare species were supported after afforestation. In particular areas of wet flush in the peatlands supported a unique and diverse spider fauna which was lost after afforestation. In contrast, the planted improved grasslands were more species rich, and supported a greater number of spider species associated with low vegetation than comparable unplanted sites. The hedgerow spider fauna did not differ notably in assemblage composition between the unplanted and planted sites. This study suggests that even in the early stages of the forest cycle (first five 
years) there is a change in the spider fauna, with the rare or specialist species being replaced by habitat generalists or species associated with forested habitats. It is also suggested that peatlands are particularly sensitive to afforestation, indicating that in terms of biodiversity loss, this habitat is the least suitable for afforestation.

5 Keywords: Spiders; Afforestation; Sitka spruce; Peatland; Grassland; Habitat specialists. 


\section{Introduction}

Afforestation causes major changes in both the abiotic and biotic aspects of an ecosystem. During the forest plantation cycle, as the habitat changes from an open to a forested environment, the greatest changes in the flora and fauna occur when the canopy closes (Wallace and Good, 1995; Humphrey et al., 1999; Jukes et al., 2001; Oxbrough et al., 2005). However, during the early stages of afforestation the silvicultural processes which take place (i.e. land preparation, chemical application, soil drainage) as well as the inevitable change in land-use that occurs (i.e. grazed to non-grazed land) are also likely to influence the organisms present.

Previous research examining the initial affects of afforestation on habitats has documented changes in soil properties (Bellot et al., 2004; Farley and Kelly, 2004), vegetation composition (Wulf, 2004), and bird diversity (Allan et al., 1997). There has however been less investigation of these effects on invertebrates, despite their prevalence in terrestrial ecosystems and importance in food webs. Spiders are a large group of terrestrial predators which are primarily affected by changes in habitat structure (Uetz, 1991). They can disperse aerially (Richter, 1970) as well as over land, giving them the ability to colonise habitats relatively quickly compared to other groups of invertebrates with a more sessile nature. This suggests that environmental changes, which occur over a relatively short period of time, for instance the first few years after afforestation, may be reflected by changes in the spider fauna.

Across Europe the majority of afforestation is carried out on former agricultural land (UNECE, 2003). Indeed, $90 \%$ of current Irish afforestation is carried out by agricultural land owners (Teagasc, 2005). Given these current planting trends it is important to assess the impact that afforestation has on the organisms which are found in pre-planting habitats, particularly less disturbed habitats of more limited 
extent. With this in mind the present study aimed to investigate the initial effects of afforestation on the ground dwelling spider fauna within three habitat types: peatlands, improved grasslands and wet grasslands, which are typically used for afforestation in Ireland.

\section{Methodology}

\subsection{Study areas and sampling design}

A paired sampling approach was used in the present study. Ideally, researchers should be able to survey a location both before and after the event being investigated (Before-After-Control-Impact design: Green, 1979). However for investigations involving land-use changes such as afforestation, which take place over many years, a sampling design which tracks sites over time is difficult to implement. Paired-site sampling designs have been successfully utilised in previous research (Kladivko et al., 1997; Berger et al., 2002; Barnett et al., 2004). This approach was adopted in the present study to allow the influence of afforestation on ground dwelling spider assemblages to be investigated over the course of one field season rather than over several years.

Ground dwelling spider assemblages were surveyed in the following habitats: peatlands, improved grasslands, wet grasslands. Twenty four matched pairs of unplanted and planted sites (eight within each habitat) were selected on the basis of habitat, soil type, and geographical location. The site-pairs within each habitat type were widely distributed across Ireland, although improved grassland sites were grouped in the South-east (Figure 1). Where possible the paired sites were adjacent to each other, although three of the pairs were separated by $1-5 \mathrm{~km}$. The habitat type of the planted sites prior to afforestation was determined by consultation with land 
owners, foresters' records and the vegetation present at the site. The planted sites were comprised of five year old stands of Sitka spruce (Picea sitchensis), which is currently the most widely planted tree species in Ireland, accounting for $65 \%$ of annual afforestation (Teagasc, 2005).

5 General environmental and habitat characteristics of the habitats surveyed are shown in Table 1. The management regime varied among the habitat types: the unplanted improved grasslands were subject to heavy grazing and were usually fertilised at least once per year. The peatlands and wet grasslands were generally under low to heavy grazing pressure, however approximately half of the wet grasslands were also subject to annual silage cutting and fertilisation. In the planted sites the ground was generally prepared by mounding with drains established at frequent intervals, although drainage was much less frequent among the improved grasslands. Fertiliser was applied to most of the peatland and wet grassland planted sites though not the improved grasslands, and herbicide use was most frequent in the grassland sites in the years following planting. In all sites the spruce trees conformed to the standard spacing for conifers of $2 \mathrm{~m} \times 2 \mathrm{~m}$. Mean tree height in the wet grasslands was $4.3 \mathrm{~m}$ $( \pm 2.6 \mathrm{SD})$, compared to $3.1 \mathrm{~m}( \pm 1.2 \mathrm{SD})$ in the improved grasslands and just $1.6 \mathrm{~m}$ $( \pm 0.7 \mathrm{SD})$ in the peatlands.

\subsection{Spider sampling}

To investigate the initial effects of afforestation within the habitats two types of sampling plot were established. Firstly, plots were located in areas of homogenous vegetation cover which took into account the major vegetation types present: these were termed standard plots; Secondly, plots were located in various features present in the habitat which may contribute to the biodiversity of a site such as wet flushes 
and the edges of ditches or streams (in the peatlands) and hedgerows (in the grasslands): these were termed supplementary microhabitat plots. To identify suitable sampling plots, both unplanted and planted sites were examined and comparable areas of habitat within each were identified. Then plots were selected by walking a transect route through the centre of these habitat areas locating the plots approximately $50 \mathrm{~m}$ apart (although sometimes at a greater distance if no suitable habitat was located at $50 \mathrm{~m}$ ) at least $50 \mathrm{~m}$ from the edge.

Pitfall traps were used to sample the ground dwelling spider assemblages within and among the habitat types. Pitfall trap catches are a function of a species' density, activity and behaviour, and as such, the data derived should not be considered a complete inventory of all the ground-dwelling species in a given habitat. Rather, they should be considered a representation of the active ground-dwelling spider fauna which are susceptible to this trapping method.

The pitfall traps consisted of a plastic cup $(7 \mathrm{~cm}$ diameter by $9 \mathrm{~cm}$ depth) which had two drainage slits cut $1 \mathrm{~cm}$ from the rim of the cup and were filled to $1 \mathrm{~cm}$ depth with ethylene glycol to act as a killing and preserving agent. Although it has been found that a trap with a diameter of $11.1 \mathrm{~cm}$ may be the most efficient for sampling ground active spiders (Brennan, 2003) a $7 \mathrm{~cm}$ was selected in the present study for logistical reasons. The cup was placed into a whole made with a bulb corer so that the rim of the cup was flush with the surface of the ground. To protect the trap from trampling in the heavily grazed sites a section of plastic piping $(7 \mathrm{~cm}$ diameter by $10 \mathrm{~cm}$ depth), was inserted into the ground, and the plastic cup was then inserted within this ring. Each sampling plot consisted of five pitfall traps, which were arranged in a $4 \times 4 \mathrm{~m}$ grid, with one trap at each corner and one in the centre in the standard plots. In the supplementary plots which sampled linear features (such as hedgerows and ditch or 
stream edges) the traps were arranged in a line along the linear feature, with each trap spaced $2 \mathrm{~m}$ apart.

Six sampling plots were established within each site (three of each plot type), each separated by a minimum of $50 \mathrm{~m}$. In two of the improved grassland planted sites however there were no supplementary features present, so only three standard plots were established. In the wet grasslands and peatlands this gave a total of 96 plots, with 48 plots each in the unplanted and planted sites, whereas in the improved grasslands there were a total of 90 plots with 48 in the unplanted and 42 in the planted sites. The traps were active from May-July (63-65 days) and were changed three times during this period, approximately every 21 days. A large number of traps were lost through trampling in five of the sites so the pitfall traps were maintained for an extra 21 days in these pairs of sites. Due to the large number of sites and the intensity of fieldwork involving invertebrates the sampling was carried out over two field seasons in 2002 and 2004. Four pairs of peatlands were sampled in 2002 and four in 2004; two pairs of wet grasslands were sampled in 2002 and six in 2004; and two pairs of improved grasslands were sampled in 2002 and six in 2004.

A x50 magnification microscope was used to identify the spiders to species level and nomenclature follows Roberts (1993), however juveniles were not identified due to the difficulty involved in species identification. Determining the distribution, rarity and ecology of Irish spiders can be problematic due to the lack of previous research. To overcome this the Provisional Atlas of British spiders (Harvey et al., 2002) was used in conjunction with the published Irish records (van Helsdingen, 1996; Roberts, 1996; McFerran, 1997; van Helsdingen, 1997; Smith, 1999; Snazell and Jonsson, 1999; Nolan, 2000a, 2000b; Cawley, 2001; Nolan, 2002a, 2000b; Fahy and Gormally, 2003). Species which occurred in less than five of the Irish counties and which are designated as 
either Nationally Scarce or recorded as Red Data Book species (Bratton, 1991) in Great Britain were considered to be rare. The species were assigned to habitat associations based on their preference for the following habitat and microhabitat characteristics: general habitat preference (open habitats, forested habitats or generalists); moisture preference (wet habitats, dry habitats or generalists); vegetation preference (ground layer, low vegetation, bushes and trees or generalists). These were determined using available literature (listed above), however due to the lack of published information on Irish spiders many of these associations were based on the species' habitat preferences in Great Britain. This was considered adequate because the climate and habitats in Ireland and Britain are similar, and it is likely that spider species will respond in a similar way.

\subsection{Habitat variables}

Vegetation cover in a $1 \mathrm{~m}^{2}$ quadrat surrounding each pitfall trap was measured in the following vertical layers: ground vegetation $(0-10 \mathrm{~cm})$, lower field layer $(>10 \mathrm{~cm}$ $50 \mathrm{~cm})$ and upper field layer $(>50 \mathrm{~cm}-200 \mathrm{~cm})$. Cover of other features such as deadwood, leaf litter and soil was also measured. Percentage cover of these variables was estimated using the Braun-Blanquet scale (Mueller-Dombois and Ellenberg, 1974), which gives numerical rankings to a range of percentages $(+=<1 \%$ cover; $1=$ $1-5 \% ; 2=6-25 \% ; 3=26-50 \% ; 4=51-75 \% ; 5=76-100 \%)$. For the analyses the appropriate median value within each range was substituted for the numerical ranking. At two locations within each plot a bulb corer was used to extract the top layer of the substrate to a depth of $15 \mathrm{~cm}$. Organic content of the soil was then calculated using the method outlined in Grimshaw (1989). Each plot was classified by habitat type according to the Irish habitat classification scheme (Fossitt, 2000). 
Several of the flushes sampled were large enough to be designated as a poor fen and flush peatland habitat type, however as these areas were still not large enough to constitute a substantial area of the site they were still considered supplementary habitats.

\subsection{Data Analysis}

NMS ordination analysis (for explanation see below) indicated that there was no difference in the spider assemblages sampled between the 2002 and 2004 fieldwork seasons, therefore these data sets were pooled in subsequent analyses. There was a significant effect of trap loss on the spider assemblages within the plots when three or more traps were missing ( $20 \%$ of the total per plot). Where possible pitfall traps from the extra sampling period were substituted for the missing traps, however where three or more traps were missing and no replacement traps were available these plots were excluded from the analyses.

Paired sample t-tests were used to examine the effect of afforestation on the spider assemblages of the standard and supplementary plots within each habitat type. The following response variables were tested: species richness, abundance, dominance and richness of the various habitat specialists. The Berger-Parker index (Berger and Parker, 1970) was used to indicate dominance, which calculates the proportion of the total abundance accounted for by the most abundant species. For these analyses the mean value of each response variable was calculated for each site. The response variables were tested for normality and homogeneity of variance and the BergerParker values were arcsin transformed. These analyses were carried out using SPSS (SPSS, 2002). 
To examine the differences in spider assemblage composition between the unplanted and planted sites among the habitat types Global Non-metric Multi-dimensional Scaling analysis (NMS), Blocked Multiple-response Permutation Procedures (MRBP) and Indicator Species Analysis were used. The NMS used plot data and the following parameter set-up: 6 initial axes, 20 runs with real data, stability criterion $=0.001,10$ iterations to evaluate stability, 250 maximum iterations, step down in dimensionality used, initial step length $=0.20$, random starting coordinates and 50 runs of the Monte Carlo test. The environmental variables were correlated with the ordination axes and those with a Pearson $\mathrm{r}^{2}>0.1$ were presented in a joint biplot ordination diagram. MRBP analysis tests the difference between pre-determined groups (site pairs) using the Euclidean distance measure. Differences are tested with the A statistic where $\mathrm{A}=$ $>0$ if the average distance is lower than that expected by chance within each group, $\mathrm{A}=0$ if average distance is equal to that expected by chance within each group and $A=1$ if the assemblages are the same within each group. The A statistic is tested for significance by comparing observed and expected values. Indicator Species Analysis combines the relative abundance and relative frequency of species within each group, identifies species with high constancy and fidelity to groups and then tests the significance of the resulting indicator value with a Monte Carlo test. These analyses used relative abundance data (to account for differences in pitfall trap efficiency caused by variation in vegetation structure; Melbourne, 1999) and were carried out using PC-ORD (McCune and Mefford, 1997).

\section{Results}

Over $14 \%$ of the traps were lost due to animal trampling. The majority of these were 
these plots excluded from the analyses this gave a total of 86 plots in the peatlands (43 planted and 43 unplanted), 70 in the improved grasslands (37 unplanted and 33 planted) and 90 in the wet grasslands (45 unplanted and 45 planted). For the paired site analyses this resulted in 6 paired peatlands, 7 paired wet grasslands and 5 paired 5 improved grasslands.

There were 33157 individuals captured from 189 species and 18 families: of these spiders 3448 were juveniles and so were excluded from the analyses. The most abundant species in the unplanted sites were Pardosa pullata (Clerck, 1757), Pardosa amentata (Clerck, 1757), Silometopus elegans (O. P.-Cambridge, 1872), Oedothorax fuscus (Blackwall, 1834) and Pachygnatha degeeri (Sundevall, 1830), each of these species constituting greater than $5 \%$ of the total adult catch within these sites. In the planted sites, P. pullata and P. amentata were the most abundant species, also constituting greater than $5 \%$ of the total adult catch each.

There were 40 species sampled that were associated with open habitats and 15 species associated with forested habitats; furthermore, two species were associated with dry habitats and 54 species associated with damp or wet habitats. The majority of species sampled were typical ground layer species (111), although 37 species were associated with low vegetation and one species associated with trees and shrubs. A full list of the species and their authorities, including their habitat associations is given in the Appendix.

There were five rare species found in the standard plots, the majority of which were only sampled in the unplanted sites. Satilatlas britteni (Jackson, 1913) is associated wet locations and was sampled in lowland and upland blanket bogs. Both Nigma puella (Simon, 1870) and Zelotes lutetianus (Koch, 1866) were sampled in the lowland blanket bogs, N. puella is usually found on trees and bushes, and Z. lutetianus is 
associated with coastal marshes and sand dunes (Harvey et al., 2002). Milleriana inerrans (O. P.-Cambridge, 1885) frequently utilises aerial dispersal and is therefore found in a variety of habitats in Britain (Harvey, et al. 2002) though it has only been recorded once in Ireland. This species was sampled in the unplanted wet grasslands.

5 Only one rare species was found solely in the planted sites, Episinus truncatus (Latrielle, 1809), which was sampled in an improved grassland site and is usually associated with heathlands (Roberts, 1993). Baryphyma gowerense (Locket, 1865), was sampled in a wet grassland standard plot (as well as in a poor fen and flush supplementary peatland plot) and has previously been found in brackish marshes (Harvey et al., 2002).

There were four rare species found in the supplementary microhabitat plots, the majority of which were only sampled in the unplanted peatlands. Meioneta mollis (O. P.- Cambridge, 1871) which was a new Irish record, and is associated with damp conditions, and S. britteni, were both sampled in poor fen and flush peatlands. $B$. gowerense was sampled in a poor fen and flush unplanted peatland plot (as well as in wet grassland standard plot). Maro sublestus (Falconer, 1915) and S. britteni, were also sampled on the edges of streams in lowland blanket bogs. Both of these species are associated with wet habitats (Harvey et al., 2002). Saloca diceros (O. P. -Cambridge, 1871) was found in both unplanted and planted hedgerows in the wet grasslands and is associated with a variety of wet habitats such as saltmarshes and Sphagnum bogs (Harvey et al., 2002).

\subsection{The affects of afforestation on species richness and abundance}

Standard plots

The mean number of species per standard plot within each habitat type is shown in Table 2. Total species richness did not differ significantly between the unplanted and planted peatland and wet grasslands; however in the improved grasslands mean 
species richness was significantly greater in the planted sites. Across the habitats total abundance and the number of open-associated and wet-associated species was greater in the unplanted sites, though for abundance this difference was not significant among the improved grasslands. In contrast, the number of species associated with forested habitats was higher in the planted sites across the habitats, though not significantly so in the wet grasslands. The number of species associated with the ground layer did not differ significantly between the unplanted and planted peatlands and wet grasslands; however in the improved grasslands the number of ground layer species supported was significantly greater in the planted sites. Similarly, the number of low vegetation species did not differ significantly among the unplanted and planted sites in the wet grasslands and peatlands, however there were significantly more of these species supported in the improved grassland planted than the unplanted sites.

Supplementary microhabitat plots

In the peatlands the number of species associated with wet habitats was significantly lower in the planted supplementary plots compared to the unplanted plots $(t=3.60$, $P=0.009, \mathrm{n}=8)$. The number of ground layer species in the peatlands showed a similar trend, however this difference was not significant $(\mathrm{t}=1.95, P=0.09, \mathrm{n}=8)$. The remaining species variables however (total richness, abundance, dominance and various habitat specialists) did not differ significantly in the peatlands. In addition to this there were no significant differences in any of the measures of the abovementioned species variables between supplementary plots in the planted and the unplanted sites within the wet and improved grasslands. 
Standard plots

The grassland and peatland spider assemblages were distinct in both the richness of the various species groups and the rare species supported (see above text, table 2 and Appendix) so these were analysed in separate ordinations. The NMS ordination of spider assemblages among the unplanted and planted grassland standard plots accounted for $84 \%$ of the variation in the data with three axes best explaining this variation (Figure 2). Axis 1, which accounted for $31 \%$ of the variation, separated the unplanted from the planted plots. Axis 2, which represented $30 \%$ of the variation, distinguished the unplanted improved grasslands from both the unplanted and planted wet grassland plots. Axis 3, which accounted for a further $22 \%$ of the variation in the species data, represented a further separation of the unplanted and planted plots. Within the habitats the spider assemblages in the unplanted and planted improved grasslands differed significantly (MRBP: $A=0.291, P=0.008$ ), whereas unplanted and planted wet grasslands plots did not (MRBP: $\mathrm{A}=0.045, P=$ $0.139)$.

The NMS ordination of the peatland standard plots accounted for $86 \%$ of the variation in spider assemblage composition (Figure 3) and was represented by three axes. Axis 1, which explained over $53 \%$ of the variation in the species data, distinguished the unplanted and planted plots which also differed significantly in assemblage composition (MRBP: $\mathrm{A}=0.162, P=0.004$ ). Across Axis 2 (which accounted for $17 \%$ of the variation) the planted plots exhibited greater variation than the unplanted plots. There was also some separation of the unplanted plots by Irish habitat classification (Figure 3). Axis 3, which accounted for $15 \%$ of the variation in the species data, further separated the planted plots, distinguishing several lowland and upland blanket bog plots from the remaining plots. 
The species with high indicator values in the unplanted sites (Table 3) are mostly species commonly found in open habitats, however several species associated with wet habitats were identified as indicators in the wet grasslands and peatlands. In the planted sites most of the species with high indicator values were generalist species commonly found in a broad range of open habitats, although $R$. lividus is a ubiquitous species which is found in both open and forested habitats, and two species associated with forested habitats were identified.

\section{Supplementary microhabitat plots}

The NMS ordination of the spider assemblages among the supplementary plots in the unplanted and planted grasslands accounted for $70 \%$ of the variation in the species data with three axes best explaining this variation (Figure 4). Axis 1, which accounted for $28 \%$ of the variation, separated the unplanted improved grassland plots from the planted plots to some degree, with the planted plots forming a relatively tight cluster. However, the assemblages of the unplanted and planted supplementary plots did not differ significantly from each other: $A=-0.020, P=0.243$ and $\mathrm{A}=0.014, P=0.170$ in the improved grasslands and wet grasslands respectively. The remaining two axes each explained $21 \%$ of the variation among the spider assemblages represented some unknown variation in the supplementary plots (hedgerows) unrelated to habitat type or site.

The NMS ordination of the spider assemblages among the supplementary plots in the unplanted and planted peatlands accounted for $77 \%$ of the variation in the species data (Figure 5). Three axes best explained the variation in the spider assemblages with Axis 1 accounting for $40 \%$, Axis 2, 20\% and Axis 3, 17\%. Axis 1 distinguished the spider assemblages of the unplanted and planted supplementary 
plots, which differed significantly (MRBP: $\mathrm{A}=0.143, P=0.006$ ). The planted plots were associated with higher cover of upper and lower field layer vegetation whereas the unplanted plots were associated with higher cover of ground vegetation. Axis 2 reflected differences in organic content and soil cover among the plots.

5 The indicator species identified in the supplementary plots among the unplanted and planted sites are shown in Table 4. The unplanted sites were characterized by open as well as generalist species, although one species was associated with wet habitats. In the planted sites species with high indicator values are associated with both open and forested areas.

\section{Discussion}

During the forest cycle there is a fundamental change in the flora and fauna at the time of canopy closure (Wallace and Good, 1995; Humphrey et al., 1999; Jukes et al., 2001; French, 2005; Oxbrough et al., 2005). Indeed, prior to this the spider assemblages resemble that of the pre-planting habitat type (Oxbrough et al., 2005). In addition to this, the present study also suggests that even in the first five years of the forest cycle the spider fauna is affected by afforestation. In particular, species associated with specific habitat characteristics of the unplanted sites were replaced by habitat generalists. Furthermore, after afforestation, a greater number of species associated with forested habitats were supported, even at this early stage in the forest plantation cycle. For instance, two forest species (L. zimmermanni and M. fuscipes) were identified as indicators of the planted peatland and improved grassland sites respectively. The five-year old spruce trees in this study had not yet reached canopy closure: the trees were spaced $2 \mathrm{~m}$ apart and were generally $2-3 \mathrm{~m}$ high (mean $2.2 \mathrm{~m}$ $\pm 0.9 \mathrm{SD}$, range $0.1-4.3 \mathrm{~m})$. However, for ground-dwelling spiders this may create some 
of the conditions characteristic of forested environments such as protection from the wind and stable microclimates (Pollard 1968).

\subsection{Peatland spider fauna}

5 There was no overall difference in the number of species supported in the peatlands after afforestation, however the composition of the spider assemblages differed between the unplanted and planted sites, being distinguished by a reduction in rare and specialist wetland species. Prior to afforestation the unplanted areas are prepared for plantation establishment to encourage more suitable conditions for tree growth. This includes the establishment of drains, which on particularly wet sites are created at frequent intervals: for instance the recommended spacing for mound drains is $8 \mathrm{~m}$ (Forest Service, 2003). Indeed, in the present study the majority of the sites had an extensive network of drains established (personal observation). The peatlands were generally the wettest sites surveyed and so drainage may have had the greatest influence on the soil moisture content in this habitat, a factor known to influence spider distribution (Usher, 1992).

The extent of the drainage may be of particular importance for the supplementary microhabitats sampled in the peatlands, especially those larger areas which were designated as poor fen and flush habitats. These areas supported a distinct spider

fauna with several rare species compared to those in the planted sites. The Irish Forestry and Water Quality Guidelines (Forest Service, 2000b) stipulate that aquatic zones ('a permanent or seasonal river, stream or lake') which are marked on Ordnance Survey six-inch maps should be protected during the afforestation process by a minimum buffer zone of $10 \mathrm{~m}$. These current guidelines are likely to exclude the supplementary flushes sampled within this survey because they are either not included in this definition or because of they are too small to be included on the six- 
inch maps, and so they may be afforded little protection during the afforestation process.

In the peatlands the vegetation structure and composition changed dramatically after afforestation. The unplanted peatlands were dominated by a mixture of mosses, sedges, low herbs and some grasses and low ericaceous shrubs. After planting, purple moor-grass (Molinia caerulea), a coarse tussocky grass, was dominant in many of the peatland sites. This may explain why the numbers of species associated with low vegetation was significantly lower in the planted peatlands; these species may have been specialised to the particular vegetation structure present on the site prior to afforestation. Changes in vegetation structure and composition could be attributed to the drier soil conditions after afforestation, but also the application of fertiliser (phosphate) which was used after afforestation on all of the peatland sites. Although fertiliser is applied to encourage crop tree growth it is also likely to influence the ground and herb vegetation present.

15

\subsection{Grassland spider fauna}

Among the grasslands the number of specialist wetland species and rare species was reduced after afforestation, again probably reflecting the influence of soil drainage but also fertiliser application in the wet grasslands. In addition to this the spider fauna of the grasslands, and in particular the improved grasslands, may have been influenced by a release from grazing pressure. The improved grassland sites were the most intensively managed of the habitats surveyed prior to afforestation, with the heaviest level of grazing. This can be seen in the present study where the unplanted improved grasslands were characterised by species such as E. atra, E. dentipalpis and O. fuscus, which are pioneer species frequently found dominating disturbed habitats (Cole et al., 2003). However after afforestation there was an increase in the overall 
number of species supported and also in the number of species associated with low vegetation (rather than ground vegetation). Grazing pressure has been found to directly influence spider diversity through the resulting decrease in vegetation structure (Dennis et al., 1998; Dennis et al., 2001). This may suggest that afforestation

5 initially benefits the spider fauna of improved grasslands, however this is unlikely to persist after canopy closure (Oxbrough et al., 2005)

It is unsurprising that the hedgerows sampled in the grasslands did not differ to a great degree in either species richness or assemblage composition between the unplanted and planted sites. Whilst hedgerows are likely to be adversely affected by the effects of shading when the trees are more developed, at this early stage in the forest plantation cycle trees of $2-3 \mathrm{~m}$ in height are unlikely to have a large impact. Furthermore, the Irish Forest Biodiversity Guidelines (Forest Service, 2000a) recommend that hedgerows be regarded as areas for biodiversity enhancement within plantations, meaning that they should remain undisturbed during the afforestation process and a $3 \mathrm{~m}$ buffer zone should be established around them (Forest Service, 2000a). This is presumably to protect them from shading and disturbance by machinery. In addition to this hedgerows may support species which inhabit the upper vegetation layers (and hence not sampled by pitfalls), so the protection of these features during the afforestation process may be important for plantation biodiversity.

\section{Conclusions}

This study indicates that peatlands are the most sensitive to afforestation of the habitats surveyed, suggesting that in terms of biodiversity loss, this habitat is the least suitable for afforestation. In particular, small areas of wet flush within peatlands, which support distinct and rare species, should be protected during the 
afforestation process. Furthermore, the loss of specialist species across all of the habitats after afforestation indicates that retained areas which are selected for biodiversity enhancement when plantations are established will benefit from as little disturbance to the habitat and pre-planting management regime as possible.

\section{Acknowledgements}

We would like to thank Julianna O'Callaghan and Maire Buckley for help with fieldwork and our colleagues on the Bioforest Project, but also Dr Alan Watt for useful comments on the experimental design and comments on the manuscript. We also thank Robert Johnston and Dr Peter Merrett for verifying the identification of several specimens. This work was carried as part of the BIOFOREST Project which is jointly funded by the Environmental Protection Agency and the National Council for Forest Research and Development (COFORD) through the National Development Plan of Ireland. 


\section{References}

Allan, D. G., Harrison, J. A., Navarro, R., van Wilgen, B. W., Thompson, M. W., 1997. The impact of commercial afforestation on bird populations in Mpumalanga Province, South Africa -- Insights from bird-atlas data. Biol. Conserv. 79, 173185.

Barnett, P. R., Whittingham, M. J., Bradbury, R. B., Wilson, J. D., 2004. Use of unimproved and improved lowland grassland by wintering birds in the UK. Agric. Ecosyst. Envir. 102, 49-60.

Bellot, J., Maestre, F. T., Chirino, E., Hernandez, N., de Urbina, J. O., 2004. Afforestation with Pinus halepensis reduces native shrub performance in a Mediterranean semiarid area. Acta Oecolog. 25, 7-15.

Berger, T. W., Neubauer, C., Glatzel, G., 2002. Factors controlling soil carbon and nitrogen stores in pure stands of Norway spruce (Picea abies) and mixed species stands in Austria. For. Ecol. Manage. 159, 3-14.

Berger, W. H., Parker, F. L., 1970. Diversity of planktibuc Foraminifera in deep sea sediments. Science 168, 1345-1347.

Bratton, J. H., 1991. British Red Data Books 3: Invertebrates other than insects. Joint Nature Conservation Committee, Peterborough.

Brennan, K., 2003. The successional response of spider communities following the multiple disturbances of mining and burning in Western Australian Jarrah forest. Aust. J. Entomol 42, 379-380.

Cawley, M., 2001. Distribution records for uncommon spiders (Araneae) including five species new to Ireland. Bull. Ir. Biogeogr. Soc 25, 135-143. 
Cole, L., McCracken, D., Downie, I. S., Dennis, P., Foster, G., Waterhouse, T., Murhpy, K., Griffin, A., Kennedy, M., 2003. Comparing the effects of farming practices on ground beetle (Coleoptera: Carabidae) and spider (Araneae) assemblages of Scottish farmland. Biodivers. Conserv. 14, 441-460.

Dennis, P., Young, M. R., Gordon, I., 1998. Distribution and abundance of small insects and arachnids in relation to structural heterogeneity of grazed, indigenous grasslands. Ecol. Entomol. 23, 253-264.

Dennis, P., Young, M. R., Bentley, C., 2001. The effect of varied grazing management on epigeal spiders, harvestmen and psuedoscorpions of Nardus stricta grassland in upland Scotland. Agri. Ecosys. Environ. 86, 39-57.

Fahy, O., Gormally, M., 2003. Two additions to the Irish spider fauna (Araneae, Linyphiidae): Walckenaeria dysderoides (Wider, 1834) and Agyneta ramosa (Jackson, 1912). Irish Nat. J. 27, 318-319.

Farley, K. A., Kelly, E. F., 2004. Effects of afforestation of a paramo grassland on soil nutrient status. For. Ecol. Manage. 195, 281-290.

Forest Service, 2000a. Forest Biodiversity Guidelines. Department of Marine and Natural Resources, Dublin.

Forest Service, 2000b. Forestry and Water Quality Guidelines. Forest Service, Department of the Marine and Natural Resources, Dublin.

Forest Service, 2003. Forestry Schemes Manual. Department of the Marine and Natural Resources, Dublin.

Fossitt, J., 2000. A Guide to Habitats in Ireland. The Heritage Council, Dublin. 
French, L., 2005. Ground flora communities in Ireland's plantation forests: their diversity, structure and composition. PhD Thesis. Department of Botany, Trinity College, Dublin.

Green, R., 1979. Sampling design and statistical methods for environmental biologists. Wiley Interscience, Chichester.

Grimshaw, H. M., 1989. Analysis of soils. In: Grimshaw, H. M. (Ed.), Chemical analysis of ecological materials. Blackwell Scientific Publications, Oxford, pp. 14-16.

Harvey, P., Nellist, D., Telfer, M., 2002. Provisional Atlas of British spiders (Arachnida, Araneae), Volume 1 \& 2. Biological Records Centre, Huntingdon.

Humphrey, J., Hawes, C., Pearce, A., Ferris-Kaan, R., Jukes, M., 1999. Relationships between insect diversity and habitat characteristics in plantation forests. For. Ecol. Manage. 113, 11-21.

Jukes, M. R., Peace, A. J., Ferris, R., 2001. Carabid beetle communities associated with coniferous plantations in Britain: the influence of site, ground vegetation and stand structure. For. Ecol. Manage. 148, 271-286.

Kladivko, E. J., Akhouri, N. M., Weesies, G., 1997. Earthworm populations and species distributions under no-till and conventional tillage in Indiana and Illinois. Soil Biol. Biochem. 29, 613-615.

Melbourne, B., 1999. Bias in the effect of habitat structure on pitfall traps:

An experimental evaluation. Aust. J. Ecol. 24, 228-239.

McCune, B. and Mefford, M., 1997. PC-ORD for Windows, Version 3.17. MJM Software, Oregon.

McFerran, D., 1997. Northern Ireland Species Inventory Spiders (Arachnida). Queens 
University Belfast, Belfast.

Mueller-Dombois, D., Ellenberg, H., 1974. Aims and methods of vegetation ecology. Wiley and sons, New York.

Nolan, M., 2000a. A provisional list of spiders (Araneae) from Lesley Gibson's survey (1979 - 1982) of Carnsore point, Co. Wexford, including one new species to Ireland, Maro Minutus (O.P - Cambridge, 1906) (Linyphiidae). Irish Nat. J. 24, 159-167.

Nolan, M., 2000b. Three spiders (Araneae) new to Ireland: Bolyphantes alticeps, Oonops domesticus and Steatoda nobilis. Irish Nat. J. 26, 200-202.

Nolan, M., 2002a. Spiders (Araneae) of montane blanket bog in county Wicklow, Ireland. Bull. Ir. Biogeogr. Soc 26, 39-59.

Nolan, M., 2002b. Uncommonly recorded spiders (Araneae) from Ireland, including one new species to the country. Bull. Ir. Biogeogr. Soc 26, 154-160.

Oxbrough, A., Gittings, T., O'Halloran, J., Giller, P. S., Smith, G. F., 2005. Structural indicators of spider communities across the forest plantation cycle. For. Ecol. Manage. 212, 171-183.

Pollard, E., 1968. Hedges IV. A comparison of Carabidae of a hedge and field site and those of a woodland glade. J. Appl. Ecol. 7, 549-557.

Richter, C., 1970. Aerial dispersal in relation to habitat in eight wolf spider species (Pardosa: Araneae: Lycosidae). Oecologia 5, 200-214.

Roberts, M., 1993. The spiders of Great Britain and Ireland. Part One. Harley Books, Colchester. 
Smith, C., 1999. Oonops domesticus (de Dalmas) new to Ireland, but unconfirmed as a native species (Araneae: Oonopidae). Irish Nat. J. 26, 127-128.

Snazell, R., Jonsson, L., 1999. Neon Robustus Lohmander (Araneae: Salticidae), a fennoscandian spider found in Scotland and Ireland. Bull. Brit. Arach. Soc. $11,251-254$.

SPSS, 2002. SPSS for Windows. Version 11.0. Chicago.

Uetz, G., 1991. Habitat structure and spider foraging. In: Bell, S., McCoy, E., Mushinsky, H. (Eds.), Habitat structure: The physical arrangement of objects in space. Chapman and Hall. London.

Usher, M., 1992. Management and diversity of arthropods in Calluna heathland. Biodivers. Conserv. 1, 63-79.

van Helsdingen, P., 1996. The spider fauna of some Irish flood plains. Irish Nat. J. 25, 285-293.

van Helsdingen, P., 1997. The spiders (Araneida) of Pollardstown Fen, Co. Kildare, Ireland. Irish Nat. J. 25, 396-404.

Wallace, H. and Good, J., 1995. Effects of afforestation on upland plant communities and implications for vegetation management. For. Ecol. Manage. 79, 29-46.

Wulf, M., 2004. Plant species richness of afforestations with different former use and habitat continuity. For. Ecol. Manage. 195, 191-204. 


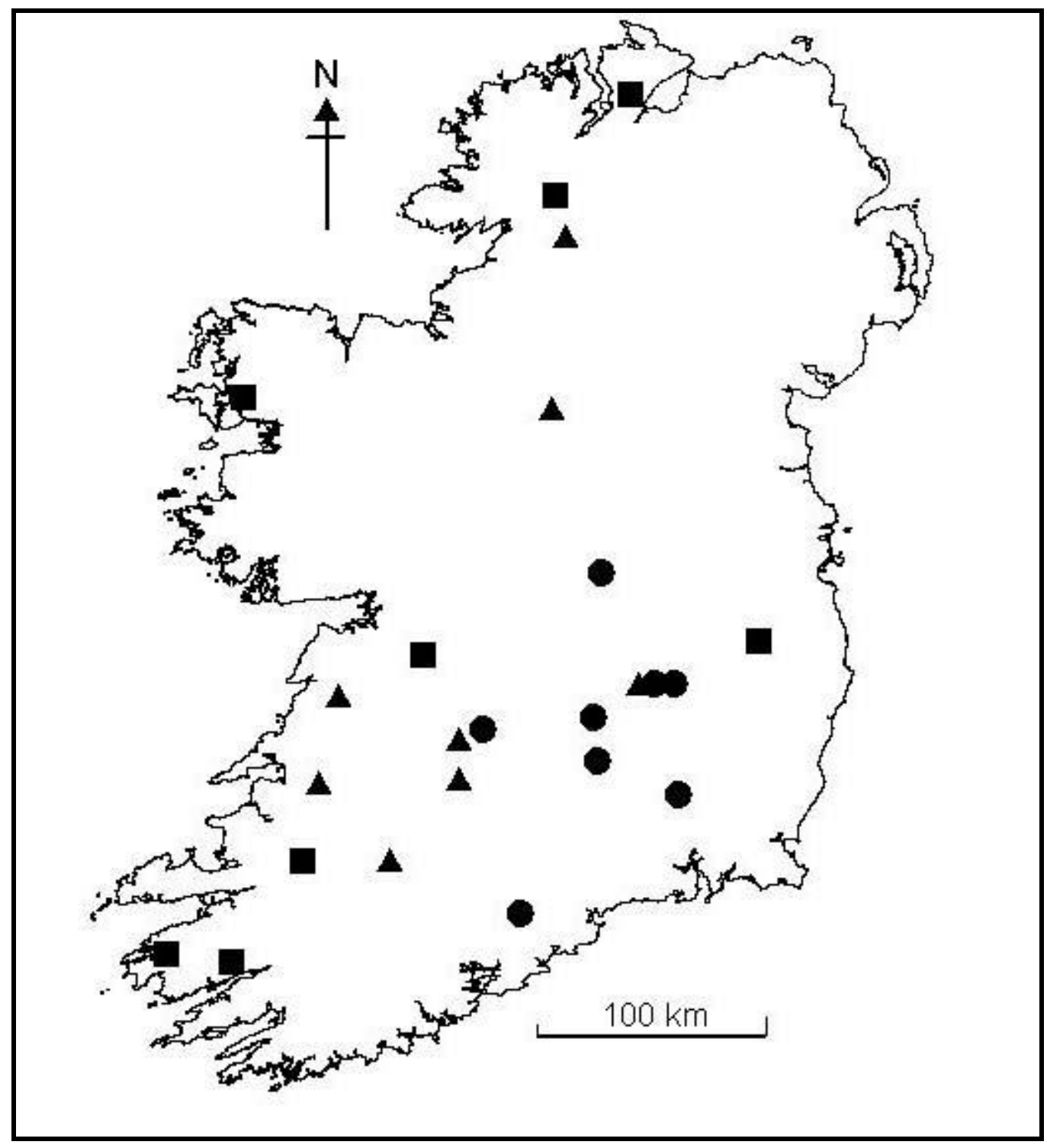

Fig.1. Distribution of paired study sites across Ireland within the following habitats: $\bullet=$ Improved 5 grassland; $\boldsymbol{\Delta}=$ Wet grassland; $\square=$ Peatland. 


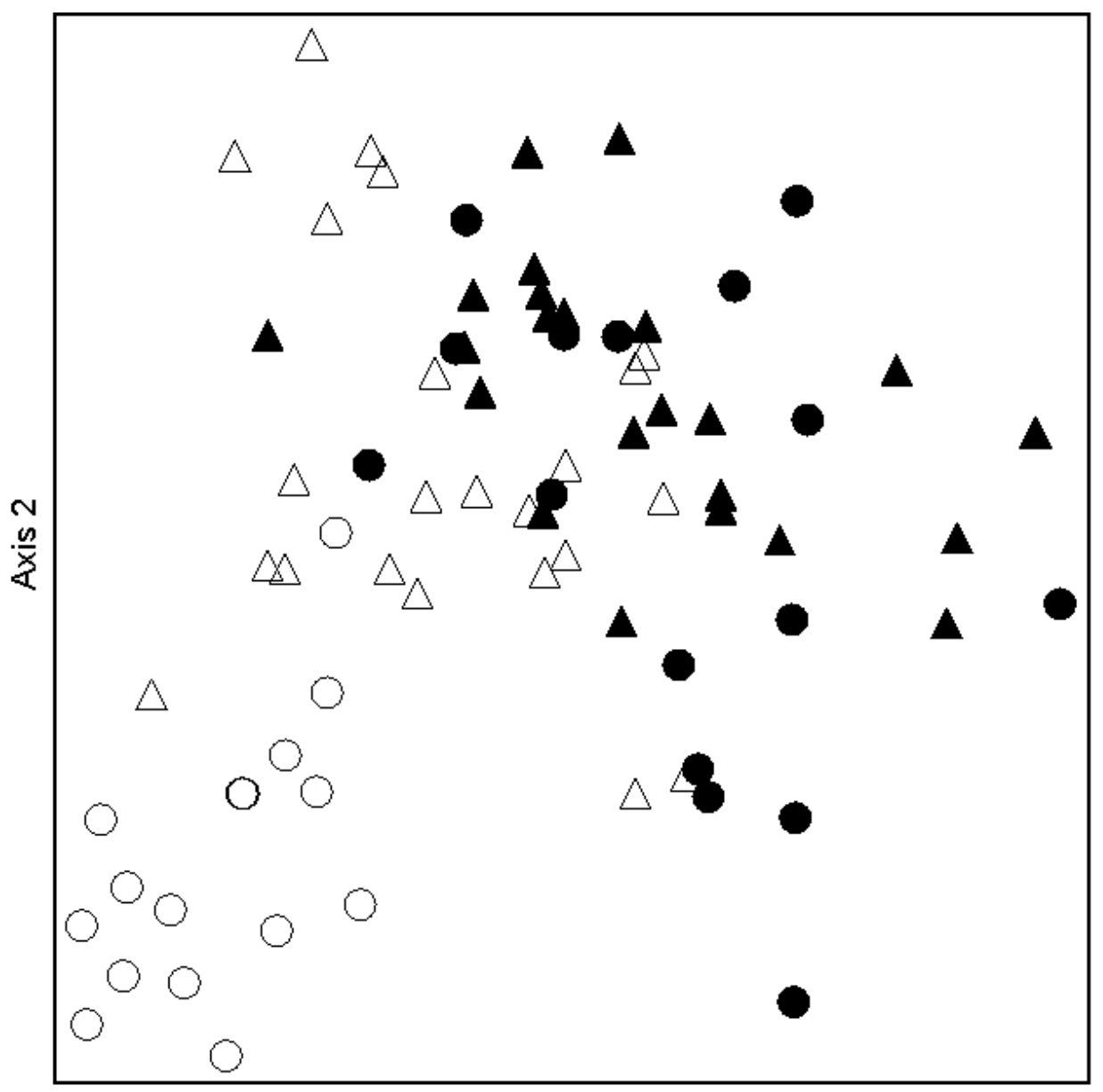

Axis 1

Fig.2. NMS ordination of the spider assemblages among the unplanted and planted standard plots in the grasslands: $\mathrm{O}=$ improved grassland unplanted; $\bullet$ = improved grassland planted; $\Delta=$ wet grassland unplanted; $\boldsymbol{\Delta}$ = wet grassland planted. Final stress for a 3-dimensional solution $=13.54$; Final 5 instability $=0.0004$. 


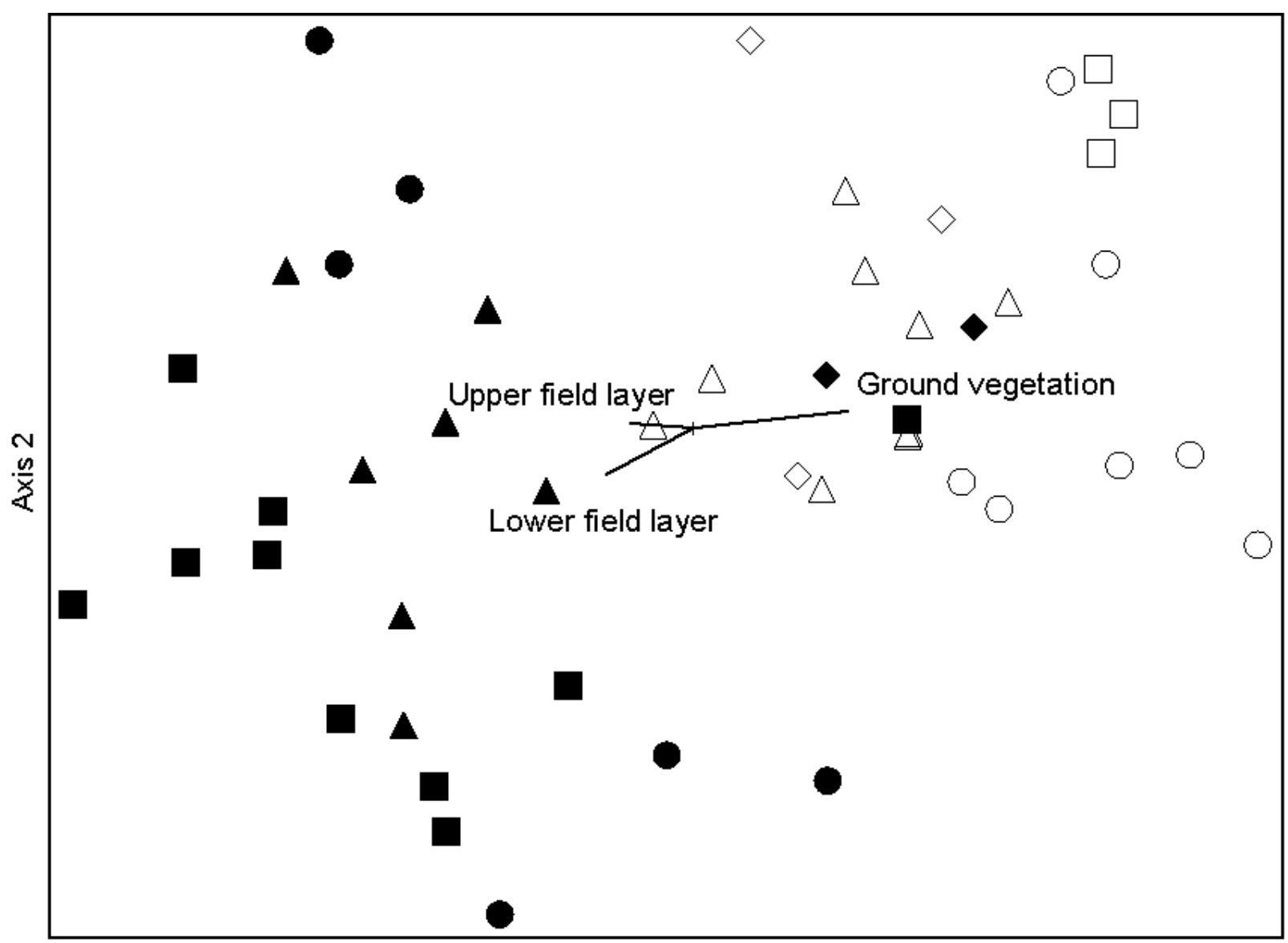

Axis 1

Fig.3. NMS ordination of the spider assemblages among the unplanted and planted standard plots in the peatlands by Irish habitat classification: $\mathrm{O}=$ Wet heath unplanted; $\bullet=$ wet heath planted; $\Delta=$ upland blanket bog unplanted; $\boldsymbol{\Lambda}=$ upland blanket bog planted; $\square=$ lowland blanket bog unplanted; $\mathbf{\square}=$ lowland blanket bog planted; $\diamond=$ cutover bog unplanted; $\bullet$ cutover bog planted. Habitat variables with a Pearson correlation $r^{2}$ value with the axes $>0.1$ are shown. Final stress for a 3 -dimensional solution $=12.83 ;$ Final instability $=0.0004$ 


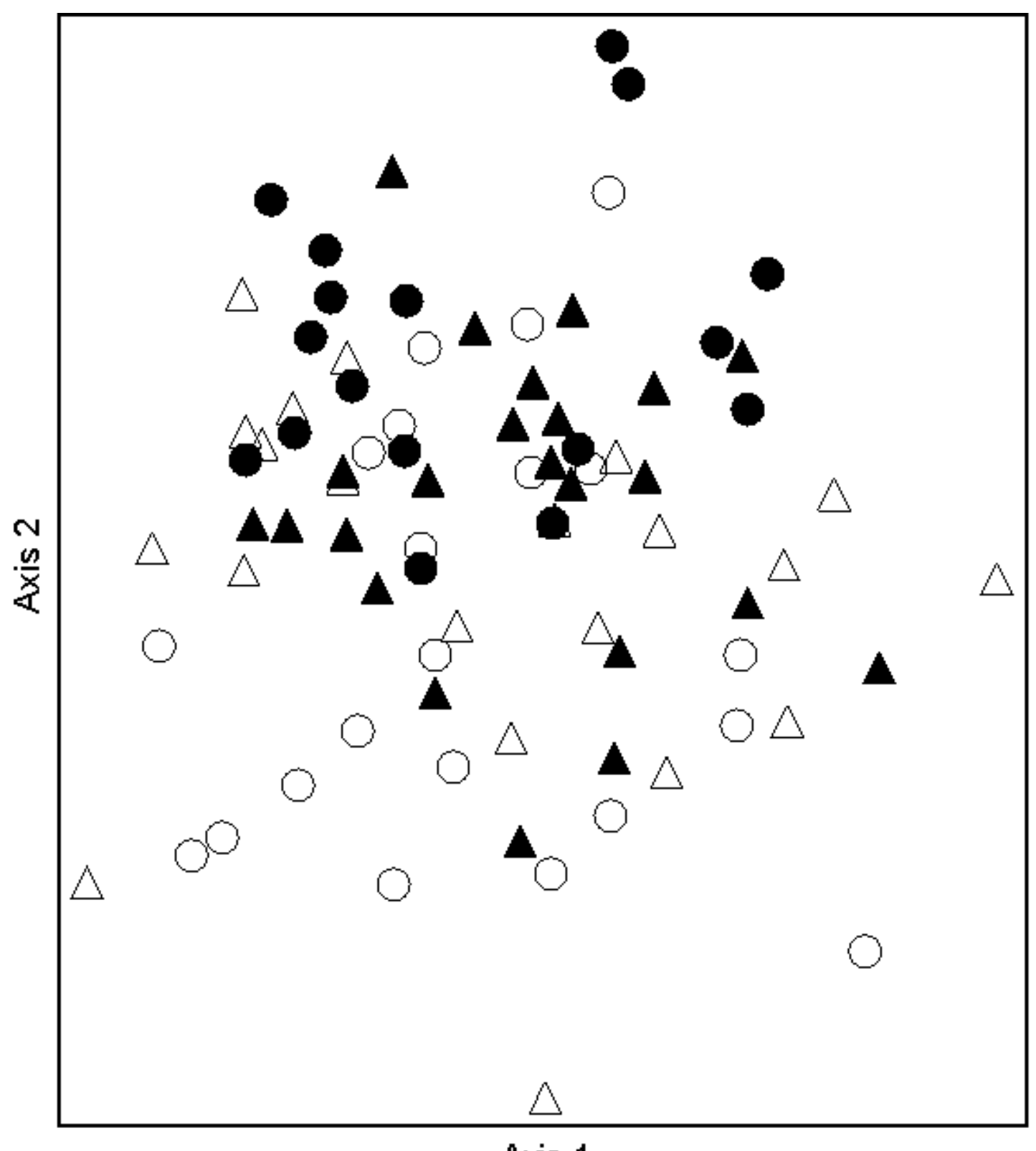

Fig.4. NMS ordination of the spider assemblages among the unplanted and planted supplementary plots in the grasslands: $\mathrm{O}=$ improved grassland unplanted; $\mathbf{\theta}=$ improved grassland planted; $\Delta=$ wet grassland unplanted; $\mathbf{\Delta}$ = wet grassland planted. Final stress for a 3-dimensional solution = 19.37;

$5 \quad$ Final instability $=0.0008$. 


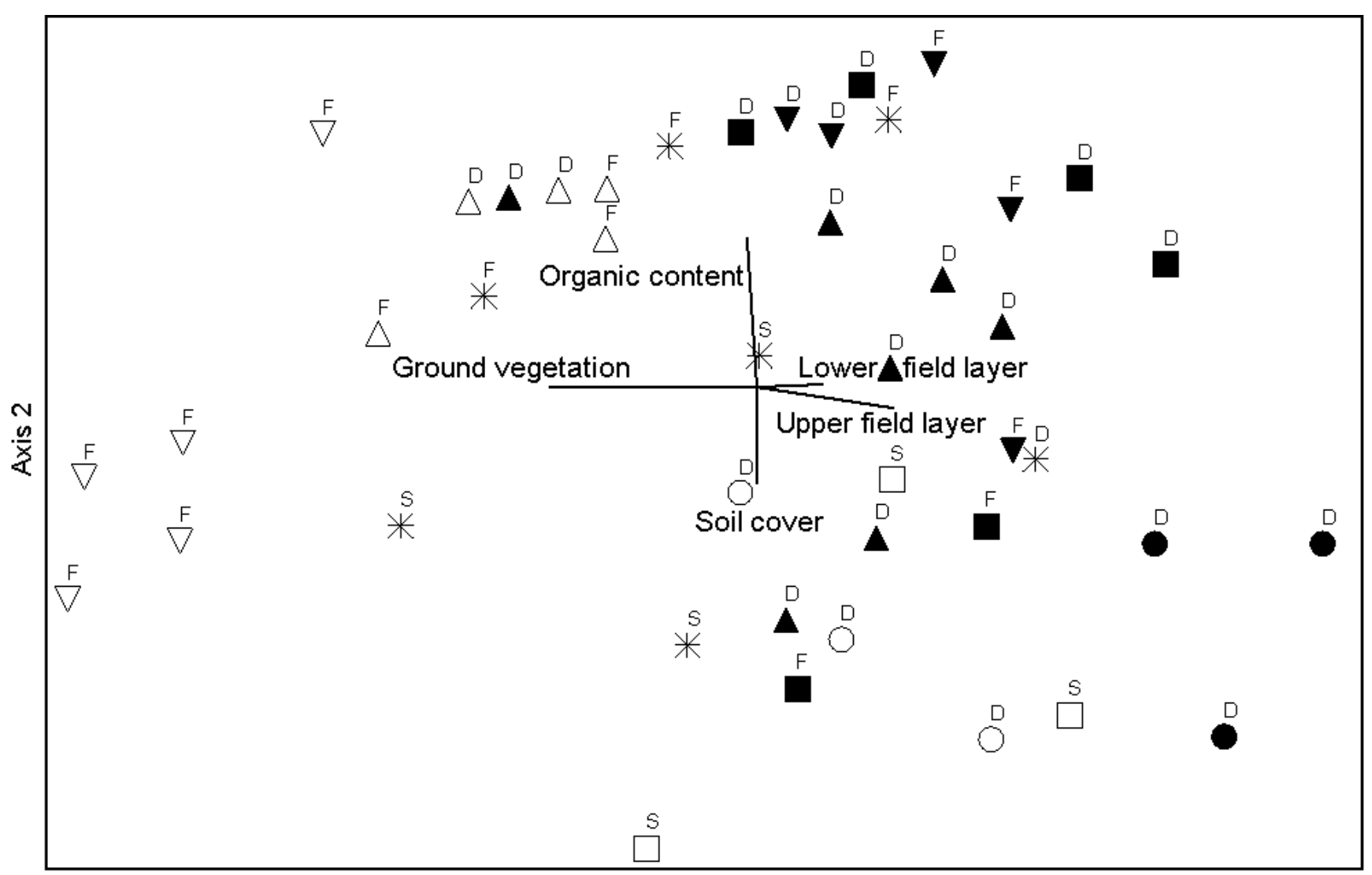

Axis 1

Fig.5. NMS ordination of the spider assemblages among the unplanted and planted supplementary plots in the peatlands by Irish habitat classification: $\mathrm{O}=$ Wet heath unplanted; - = wet heath planted; $\Delta=$ upland blanket bog unplanted; $\mathbf{\Lambda}=$ upland blanket bog planted; $\square$

$5=$ lowland blanket bog unplanted; $\mathbf{\square}=$ lowland blanket bog planted; $\nabla=$ poor fen and flush unplanted; $\boldsymbol{\nabla}=$ poor fen and flush planted; $\star$ = cutover bog unplanted. Letter above plot symbol denotes supplementary plot type: $\mathrm{F}$ = flush; $\mathrm{S}$ = edge of stream; $\mathrm{D}=$ edge of ditch. Habitat variables with a Pearson correlation $\mathrm{r}^{2}$ value with the axes $>0.1$ are shown. Final stress for a 3-dimensional solution $=15.67$; Final instability $=0.0004$. 
Table 1

Environmental and habitat characteristics among the habitats and planting types $(\mathrm{U}=$ Unplanted, $\mathrm{P}=\mathrm{Planted})$. Mean $\pm \mathrm{SD}$ and range of altitude is shown.

\begin{tabular}{|c|c|c|c|c|}
\hline Fossitt (2000) habitat type & Soil type & Altitude (m) & Drainage & Common plant species \\
\hline Peatland (U) & Peat & $143 \pm 78,20-250$ & Poor & $\begin{array}{l}\text { Molinia caerulea, Calluna vulgaris, Eriophorum angustifolium, } \\
\text { Eriophorum vaginatum, Sphagnum mosses }\end{array}$ \\
\hline Peatland $(\mathrm{P})$ & Peat & $136 \pm 73,15-225$ & Moderate & Molinia caerulea, Calluna vulgaris \\
\hline Wet grassland $(\mathrm{U})$ & Gley & $100 \pm 42,45-175$ & Moderate & $\begin{array}{l}\text { Juncus acutiflorus, Juncus effuses, Agrostis stolonifera, Molinea } \\
\text { caerulea }\end{array}$ \\
\hline Wet grassland $(\mathrm{P})$ & Gley & $101 \pm 53,45-190$ & Moderate & $\begin{array}{l}\text { Agrostis stolonifera, Juncus acutiflorus, Juncus effusus, Holcus } \\
\text { lanatus, Molinea caerulea }\end{array}$ \\
\hline Improved grassland (U) & Brown earth/ Brown podzolic & $164 \pm 79,45-300$ & Good & $\begin{array}{l}\text { Lolium perenne, Agrostis stolonifera, Holcus lanatus, Cynosurus } \\
\text { cristatus }\end{array}$ \\
\hline Improved grassland $(\mathrm{P})$ & Brown earth/ Brown podzolic & $166 \pm 78,45-290$ & Good & $\begin{array}{l}\text { Agrostis stolonifera, Holcus lanatus, Elytrigia repens, Festuca } \\
\text { rubra }\end{array}$ \\
\hline
\end{tabular}


Table 2

Mean \pm SE species richness, abundance, dominance and richness (S) of habitat specialists per standard plot in the unplanted and planted sites within each habitat type. Paired sample t-test statistics and associated significance between the unplanted and planted sites within each habitat are shown.

\begin{tabular}{llllllllll}
\hline & \multicolumn{3}{c}{ Peatland } & \multicolumn{3}{c}{ Wet grassland } & \multicolumn{3}{c}{ Improved grassland } \\
\cline { 2 - 10 } & Unplanted & Planted & $\mathrm{t}(\mathrm{df}=7)$ & Unplanted & Planted & $\mathrm{t}(\mathrm{df}=7)$ & Unplanted & Planted & $\mathrm{t}(\mathrm{df}=5)$ \\
\hline Species richness & $24.1 \pm 1.6$ & $23.0 \pm 1.6$ & 0.82 & $22.0 \pm 2.3$ & $20.0 \pm 1.1$ & 1.15 & $16.3 \pm 1.5$ & $20.9 \pm 0.9$ & $-3.63^{*}$ \\
Total abundance & $198 \pm 42$ & $91 \pm 17$ & $4.25^{* *}$ & $182 \pm 32$ & $77 \pm 13$ & $4.41^{* *}$ & $173 \pm 42$ & $99 \pm 19$ & $2.04^{\dagger}$ \\
Berger-Parker dominance & $0.32 \pm 0.09$ & $0.21 \pm 0.03$ & $4.01^{* *}$ & $0.35 \pm 0.04$ & $0.26 \pm 0.03$ & 1.5 & $0.33 \pm 0.05$ & $0.31 \pm 0.05$ & 0.32 \\
Open-associated S & $6.6 \pm 0.6$ & $5.0 \pm 0.4$ & $2.71^{*}$ & $7.6 \pm 0.8$ & $5.5 \pm 0.5$ & $4.47^{* *}$ & $7.5 \pm 0.7$ & $5.5 \pm 0.7$ & $2.48^{*}$ \\
Forest-associated S & $0.7 \pm 0.2$ & $1.3 \pm 0.2$ & $-2.60^{*}$ & $0.5 \pm 0.1$ & $1.1 \pm 0.4$ & -1.77 & $0.5 \pm 0.2$ & $1.2 \pm 0.1$ & $-3.31^{*}$ \\
Wet-associated S & $8.0 \pm 0.9$ & $5.8 \pm 0.5$ & $2.16^{\dagger}$ & $8.5 \pm 0.9$ & $6.4 \pm 1.0$ & $3.85^{* *}$ & $6.8 \pm 0.3$ & $4.4 \pm 0.6$ & $3.31^{*}$ \\
Ground-layer associated S & $17.2 \pm 1.3$ & $15.8 \pm 1.4$ & 1.64 & $14.5 \pm 1.6$ & $13.9 \pm 0.8$ & 0.51 & $9.6 \pm 0.6$ & $13.4 \pm 1.1$ & $-2.98^{*}$ \\
Low vegetation associated S & $2.9 \pm 0.3$ & $2.5 \pm 0.5$ & 0.73 & $2.6 \pm 0.5$ & $2.5 \pm 0.4$ & 0.35 & $1.6 \pm 0.5$ & $2.6 \pm 0.3$ & $-3.00^{*}$ \\
\hline
\end{tabular}

$\dagger P=0.1-0.05 ;{ }^{*} P<0.05 ;{ }^{* *} P<0.01$. 
Table 3

Indicator Species Analysis of the standard plots in the unplanted (U) and planted (P) sites within each habitat group. Species with a significant maximum indicator value $>50 \%$ and associated significance (Monte Carlo test) are indicated by bold type. The habitat association 5 of each species is also shown: $\mathrm{O}=$ Open habitats; $\mathrm{F}=$ Forested habitats; $\mathrm{W}=$ Wet habitats; GL

$=$ Ground layer.

\begin{tabular}{|c|c|c|c|c|c|c|c|}
\hline & \multirow{2}{*}{ Habitat } & \multicolumn{2}{|c|}{ Peatland } & \multicolumn{2}{|c|}{ Wet grassland } & \multicolumn{2}{|c|}{ Improved grassland } \\
\hline & & $\mathrm{U}$ & $\mathrm{P}$ & $\mathrm{U}$ & $\mathrm{P}$ & $\mathrm{U}$ & $\mathrm{P}$ \\
\hline Pardosa pullata & $\mathrm{O}, \mathrm{GL}$ & $70 * * *$ & 15 & 50 & 40 & 26 & 49 \\
\hline Pirata piraticus & W, GL & $67^{* *}$ & 16 & $71^{* * *}$ & 4 & 1 & 11 \\
\hline Silometopus. elegans & $\mathrm{O}, \mathrm{W}, \mathrm{GL}$ & $58^{*}$ & 14 & 12 & 0 & 9 & 2 \\
\hline Walckenaeria vigilax & W, GL & $54^{* *}$ & 3 & 36 & 16 & 1 & 5 \\
\hline Pocadicnemis pumila & $\mathrm{O}$ & 16 & $83^{* * *}$ & 12 & $66^{* *}$ & 2 & $75^{* * *}$ \\
\hline Lepthyphantes zimmermanni & $\mathrm{F}, \mathrm{GL}$ & 3 & $73 * * *$ & 10 & 42 & 3 & 31 \\
\hline Oedothorax gibbosus & $\mathrm{O}, \mathrm{W}, \mathrm{GL}$ & 10 & $65^{* * *}$ & 7 & $52^{*}$ & 14 & 30 \\
\hline Bathyphantes gracilis & GL & 1 & $54^{* *}$ & 61 & 31 & 49 & 51 \\
\hline Robertus lividus & GL & 5 & $50 * *$ & 2 & $51^{* *}$ & 0 & $56^{* *}$ \\
\hline Oedothorax. fuscus & $\mathrm{O}, \mathrm{W}, \mathrm{GL}$ & 7 & 1 & $63^{* * *}$ & 0 & $100 * * *$ & 0 \\
\hline Erigone atra & $\mathrm{O}, \mathrm{GL}$ & 11 & 1 & $50^{* *}$ & 5 & $97^{* * *}$ & 1 \\
\hline Bathyphantes paroulus & GL & 8 & 40 & 13 & $64^{* *}$ & 0 & $79 * * *$ \\
\hline Lepthyphantes ericaeus & GL & 6 & 49 & 10 & $56^{*}$ & 0 & $62^{* * *}$ \\
\hline Erigone dentipalpis & $\mathrm{O}, \mathrm{GL}$ & 12 & 1 & $26^{*}$ & 0 & $100 * * *$ & 0 \\
\hline Pardosa palustris & $\mathrm{O}, \mathrm{GL}$ & 27 & $0^{* *}$ & $40^{*}$ & 1 & $69 * * *$ & 0 \\
\hline Pocadicnemis juncea & $\mathrm{O}$ & 4 & $41^{*}$ & 19 & 45 & 2 & $72 * *$ \\
\hline Monocephalus fuscipes & $\mathrm{F}, \mathrm{GL}$ & 6 & 7 & 0 & $34^{* *}$ & 0 & $62 * * *$ \\
\hline Walckenaeria acuminata & GL & 6 & 8 & 5 & 16 & 0 & $56 * *$ \\
\hline
\end{tabular}

* $P<0.05$; ** $P<0.01$; *** $P<0.001$. 
Table 4

Indicator Species Analysis of the supplementary microhabitat plots in the unplanted (U) and planted $(\mathrm{P})$ sites within each habitat group. Species with a significant maximum indicator value $>50 \%$ and associated significance (Monte Carlo test) are indicated by bold type. The habitat association of each species is also shown: $\mathrm{O}=$ Open habitats; $\mathrm{W}=$ Wet habitats; $\mathrm{GL}=$ Ground layer.; LV = Low vegetation.

\begin{tabular}{|c|c|c|c|c|c|c|c|}
\hline & \multirow[b]{2}{*}{ Habitat } & \multicolumn{2}{|c|}{ Peatland } & \multicolumn{2}{|c|}{ Wet grassland } & \multicolumn{2}{|c|}{ Improved grassland } \\
\hline & & $\mathrm{U}$ & $\mathrm{P}$ & $\mathrm{U}$ & $\mathrm{P}$ & $\mathrm{U}$ & $\mathrm{P}$ \\
\hline Pardosa pullata & $\mathrm{O}, \mathrm{GL}$ & $87^{* * *}$ & 10 & 15 & 29 & 15 & 29 \\
\hline Walckenaeria. vigilax & $\mathrm{W}, \mathrm{GL}$ & $69^{* * *}$ & 3 & 17 & 9 & 17 & 9 \\
\hline Pachygnatha degeeri & LV & $50^{* *}$ & 5 & 12 & 1 & 12 & 1 \\
\hline Pocadicnemis. pumila & $\mathrm{O}$ & 22 & $78^{* *}$ & 23 & 27 & 23 & 27 \\
\hline Pocadicnemis. juncea & $\mathrm{O}$ & 8 & $45^{*}$ & 19 & $54^{*}$ & 22 & $61^{*}$ \\
\hline Lepthyphantes tenuis & GL & 39 & 12 & 23 & 18 & $75^{* * *}$ & 8 \\
\hline Erigone atra & $\mathrm{O}, \mathrm{GL}$ & 4 & 0 & 13 & 0 & $65^{* * *}$ & 1 \\
\hline Leptorhoptrum robustum & $\mathrm{W}, \mathrm{GL}$ & 0 & 5 & 30 & 1 & $50^{*}$ & 3 \\
\hline Bathyphantes. parvulus & GL & 17 & 16 & 6 & $49^{*}$ & 17 & $73^{* * *}$ \\
\hline Lepthyphantes. ericaeus & GL & 27 & 41 & 20 & 30 & 13 & $66^{* *}$ \\
\hline Walckenaeria. acuminata & GL & 16 & 5 & 7 & 17 & 5 & $50^{*}$ \\
\hline
\end{tabular}

${ }^{*} P<0.05 ;{ }^{* *} P<0.01 ;{ }^{* * *} P<0.001$. 
Appendix The number of individual spiders sampled within each habitat type, site type (unplanted and planted) and plot type $(\mathrm{O}=$ open, $\mathrm{L}=$ linear $), \mathrm{n}=$ number of plots. The habitat associations of each species used in the analyses are also given: $\mathrm{O}=\mathrm{Open}$ habitats; $\mathrm{F}=\mathrm{Forested}$ habitats; $\mathrm{D}=\mathrm{Dry}$ habitats; $\mathrm{W}=$ Wet habitats; GL = Ground layer; LV = Low vegetation; UV = Upper vegetation (Shrubs and trees); - = Habitat generalists.

\begin{tabular}{|c|c|c|c|c|c|c|c|c|c|c|c|c|c|}
\hline & \multicolumn{4}{|c|}{ Peatlands } & \multicolumn{4}{|c|}{ Wet grasslands } & \multicolumn{4}{|c|}{ Improved grasslands } & \multirow[t]{3}{*}{ Habitat } \\
\hline & \multicolumn{2}{|c|}{ Unplanted } & \multicolumn{2}{|c|}{ Planted } & \multicolumn{2}{|c|}{ Unplanted } & \multicolumn{2}{|c|}{ Planted } & \multicolumn{2}{|c|}{ Unplanted } & \multicolumn{2}{|c|}{ Planted } & \\
\hline & $\begin{array}{c}\mathrm{O} \\
(\mathrm{n}=35)\end{array}$ & $\begin{array}{c}\mathrm{L} \\
(\mathrm{n}=13)\end{array}$ & $\begin{array}{c}\mathrm{O} \\
(\mathrm{n}=29)\end{array}$ & $\begin{array}{c}\mathrm{L} \\
(\mathrm{n}=18)\end{array}$ & $\begin{array}{c}\mathrm{O} \\
(\mathrm{n}=24)\end{array}$ & $\begin{array}{c}\mathrm{L} \\
(\mathrm{n}=24)\end{array}$ & $\begin{array}{c}\mathrm{O} \\
(\mathrm{n}=24)\end{array}$ & $\begin{array}{c}\mathrm{L} \\
(\mathrm{n}=24)\end{array}$ & $\begin{array}{c}\mathrm{O} \\
(\mathrm{n}=24)\end{array}$ & $\begin{array}{c}\mathrm{L} \\
(\mathrm{n}=24)\end{array}$ & $\begin{array}{c}\mathrm{O} \\
(\mathrm{n}=24)\end{array}$ & $\begin{array}{c}\mathrm{L} \\
(\mathrm{n}=18)\end{array}$ & \\
\hline Agelena labyrinthica (Clerck, 1757) & 0 & 0 & 0 & 0 & 1 & 0 & 0 & 0 & 0 & 0 & 0 & 0 & LV \\
\hline Agroeca proxima (O.P.-Cambridge, 1871) & 1 & 0 & 0 & 2 & 1 & 0 & 0 & 0 & 0 & 0 & 0 & 0 & LV \\
\hline Agyneta cauta (O.P.-Cambridge, 1902) & 10 & 0 & 26 & 0 & 0 & 0 & 0 & 0 & 0 & 0 & 0 & 0 & GL \\
\hline Agyneta conigera (O.P.-Cambridge, 1863) & 3 & 0 & 5 & 2 & 0 & 2 & 2 & 2 & 0 & 3 & 0 & 2 & - \\
\hline Agyneta decora (O.P.-Cambridge, 1871) & 66 & 45 & 45 & 15 & 5 & 0 & 0 & 0 & 12 & 4 & 1 & 0 & - \\
\hline Agyneta olivacea (Emerton, 1882) & 293 & 176 & 178 & 146 & 2 & 1 & 0 & 1 & 0 & 0 & 1 & 0 & W, GL \\
\hline Agyneta ramosa (Jackson, 1912) & 4 & 9 & 5 & 6 & 8 & 29 & 4 & 20 & 0 & 4 & 1 & 8 & W, GL \\
\hline Agyneta subtilis (O.P.-Cambridge, 1863) & 63 & 49 & 64 & 35 & 6 & 48 & 8 & 57 & 0 & 21 & 0 & 8 & GL \\
\hline Allomengea vidua (Koch, 1879) & 0 & 0 & 0 & 0 & 0 & 0 & 1 & 0 & 0 & 0 & 0 & 0 & W, LV \\
\hline Alopecosa pulverulenta (Clerck, 1757) & 61 & 7 & 0 & 3 & 14 & 1 & 4 & 4 & 3 & 1 & 9 & 3 & $\mathrm{O}, \mathrm{GL}$ \\
\hline Antistea elegans (Blackwall, 1841) & 116 & 10 & 18 & 4 & 38 & 7 & 6 & 8 & 0 & 0 & 0 & 0 & $\mathrm{O}, \mathrm{W}, \mathrm{GL}$ \\
\hline Aphileta misera (O.P.-Cambridge, 1882) & 0 & 1 & 0 & 0 & 0 & 0 & 0 & 0 & 0 & 0 & 0 & 0 & $\mathrm{O}, \mathrm{W}$ \\
\hline Araeoncus crassiceps (Westring, 1861) & 18 & 0 & 0 & 0 & 0 & 0 & 0 & 0 & 0 & 0 & 0 & 0 & W, GL \\
\hline Arctosa leopardus (Sundevall, 1843) & 95 & 1 & 0 & 1 & 0 & 0 & 0 & 0 & 0 & 0 & 0 & 0 & $\mathrm{O}, \mathrm{W}, \mathrm{GL}$ \\
\hline Asthenargus paganus (Simon, 1884) & 0 & 0 & 0 & 0 & 0 & 0 & 1 & 0 & 0 & 2 & 0 & 1 & $\mathrm{~F}, \mathrm{GL}$ \\
\hline Baryphyma gowerense (Locket, 1965) & 1 & 0 & 2 & 1 & 4 & 0 & 0 & 0 & 0 & 0 & 0 & 0 & $\mathrm{O}, \mathrm{W}$ \\
\hline Baryphyma trifons (O.P.-Cambridge, 1863) & 3 & 1 & 2 & 5 & 14 & 3 & 17 & 4 & 1 & 1 & 19 & 0 & $\mathrm{O}, \mathrm{W}, \mathrm{GL}$ \\
\hline Bathyphantes approximatus (O.P.-Cambridge, 1871) & 0 & 0 & 0 & 0 & 8 & 2 & 4 & 0 & 0 & 0 & 6 & & W, GL \\
\hline Bathyphantes gracilis (Blackwall, 1841) & 12 & 57 & 96 & 94 & 188 & 27 & 73 & 35 & 197 & 50 & 172 & 41 & GL \\
\hline Bathyphantes nigrinus (Westring, 1851) & 2 & 0 & 0 & 2 & 5 & 29 & 14 & 26 & 1 & 8 & 38 & 14 & GL \\
\hline
\end{tabular}


Bathyphantes parvulus (Westring, 1851)

Bathyphantes setiger (O.P.-Cambridge, 1894)

Bolyphantes luteolus (Blackwall, 1833)

Centromerita bicolor (Blackwall, 1833)

Centromerita concinna (Thorell, 1875)

Centromerus sylvaticus (Blackwall, 1841)

Centromerus dilutus (O.P.-Cambridge, 1875)

Ceratinella brevipes (Westring, 1851)

Ceratinella brevis (Wider, 1834)

Ceratinella scabrosa (O.P.-Cambridge, 1871)

Clubiona comta (C.L. Koch, 1839)

Clubiona diversa (O.P.-Cambridge, 1862)

Clubiona lutescens (Westring, 1851)

Clubiona neglecta (O.P.-Cambridge, 1862)

Clubiona reclusa (O.P.-Cambridge, 1863)

Clubiona stagnatilis (Kulczynski, 1897)

Clubiona trivialis (C.L.Koch, 1843)

Cnephalocotes obscurus (Simon, 1884)

Cryphoeca sylvicola (C.L.Koch, 1834)

Dicymbium nigrum (Blackwall, 1834)

Dicymbium tibiale (Blackwall, 1836)

Diplocephalus cristatus (Blackwall, 1833)

Diplocephalus latifrons (O.P.-Cambridge, 1863)

Diplocephalus permixtus (O.P.-Cambridge, 1871)

Diplocephalus picinus (Blackwall, 1831)

Diplostylor concolor (Wider, 1834)

Dismodicus bifrons (Blackwall, 1841)

Dolomedes fimbriatus (Clerck, 1757)

Drassodes cupreus (Blackwall, 1834)

Drassodes lapidosus (Walckenaer, 1802)

Drepanotylus uncatus (O.P.-Cambridge, 1873)

Dysdera crocata (C. L. Koch, 1838

Enoplognatha ovata (Clerck, 1757)

$\begin{array}{cccc}17 & 37 & 35 & 19 \\ 1 & 0 & 0 & 0 \\ 0 & 0 & 1 & 0 \\ 0 & 0 & 0 & 0 \\ 15 & 2 & 2 & 0 \\ 0 & 0 & 0 & 0 \\ 3 & 0 & 6 & 3 \\ 107 & 66 & 110 & 70 \\ 32 & 0 & 13 & 15 \\ 0 & 0 & 1 & 0 \\ 0 & 0 & 0 & 0 \\ 3 & 0 & 0 & 1 \\ 0 & 0 & 0 & 0 \\ 0 & 0 & 0 & 0 \\ 2 & 0 & 0 & 3 \\ 2 & 0 & 1 & 0 \\ 1 & 0 & 1 & 0 \\ 19 & 6 & 4 & 0 \\ 0 & 0 & 0 & 1 \\ 13 & 26 & 5 & 2 \\ 2 & 0 & 4 & 4 \\ 1 & 0 & 0 & 0 \\ 1 & 0 & 0 & 0 \\ 12 & 4 & 3 & 2 \\ 1 & 0 & 0 & 0 \\ 0 & 0 & 0 & 0 \\ 22 & 7 & 28 & 12 \\ 5 & 0 & 2 & 3 \\ 18 & 0 & 0 & 1 \\ 1 & 1 & 1 & 0 \\ 1 & 0 & 0 & 0 \\ 0 & 0 & 0 & 0 \\ 0 & 2 & 5 & 0\end{array}$

20
0
0
0
1
0
0
5
3
85
5
0
0
0
5
0
0
0
1
8
0
0
4
11
0
15
35
0
0
0
0
0
3
0
0
0
0
0
0
0
0

103
0
0
0
0
0
2
10
0
5
0
0
0
0
1
0
0
0
0
21
2
0
1
4
0
0
13
8
0
0
0
0
4

0
0
0
0
0
0
0
0
0
0
0
0
0
0
0
0
0

62
0
0
0
0
0
0
11
2
65
4
0
0
0
3
0
0
0
2
14
0
0
10
9
0
5
34
0
0
0
0
0
2

0
0

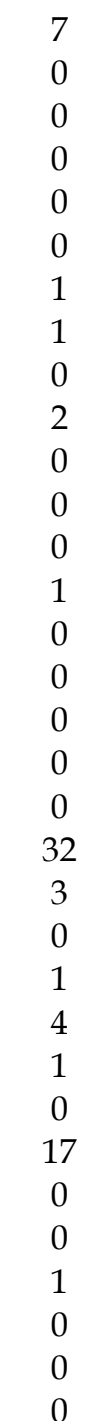

52
0
0
0
1
0
1
6
7
47
4
0
0
0
3
0
0
0
1
4
2
0
3
0
1
9
30
0
0
0
0

192
0
0
1
0
0
1
7
1
7
0
0
0
0
8
0
0
0
2
38
3
0
1
1
0
8
37
0
0
0
0
0
3

GL

W, GL

GL

GL

GL

GL

GL

GL

GL

UV

LV

LV

LV

W, LV

$\mathrm{D}, \mathrm{LV}$

GL

GL

GL

F, GL

W, GL

GL

GL

GL

$\mathrm{O}, \mathrm{W}$

$\mathrm{O}, \mathrm{GL}$

$\mathrm{O}, \mathrm{GL}$

$\mathrm{O}, \mathrm{W}$

W 
Enoplognatha thoracia (Hahn, 1833)

Episinus angulatus (Blackwall, 1836)

Episinus truncatus (Latrielle, 1809)

Erigone atra (Blackwall, 1833)

Erigone dentipalpis (Wider, 1843)

Erigone longipalpis (Sundevall, 1830)

Erigonella hiemalis (Blackwall, 1841)

Erigonella ignobilis (O.P.-Cambridge, 1871)

Ero cambridgei (Kulczynski, 1911)

Ero furcata (Villers, 1789)

Euryopsis flavomaculata (C. L. Koch, 1836)

Gnathonarium dentatum (Wider, 1834)

Gonatium rubens (Blackwall, 1833)

Gongylidiellum vivum (O.P.-Cambridge, 1875)

Gongylidiellum latebricola (O.P.-Cambridge, 1871)

Gongylidum rufipes (Linnaeus, 1758)

Hahnia montana (Blackwall, 1841)

Hahnia nava (Blackwall, 1841)

Haplodrassus signifier (C.L. Koch, 1839)

Hilaira excisa (O. P.-Cambridge, 1870)

Hypomma bituberculatum (Wider, 1834)

Hypomma cornutum (Blackwall, 1833)

Hyposinga pygmaea (Sundevall, 1831)

Hypselistes jacksoni (O.P.-Cambridge, 1902)

Kaestneria dorsalis (Wider, 1834)

Kaestneria pullata (O.P.-Cambridge, 1863)

Lepthyphantes alacris (Blackwall, 1853)

Lepthyphantes angulatus (O. P. -Cambridge, 1871)

Lepthyphantes cristatus (Menge, 1866)

Lepthyphantes ericaeus (Blackwall, 1853)

Lepthyphantes flavipes (Blackwall, 1854)

Lepthyphantes mengei (Kulczynski, 1887)

Lepthyphantes minutus (Blackwall, 1833)

$\begin{array}{cccc}1 & 0 & 0 & 0 \\ 0 & 0 & 1 & 0 \\ 0 & 0 & 0 & 0 \\ 7 & 0 & 1 & 0 \\ 10 & 0 & 0 & 0 \\ 0 & 0 & 0 & 0 \\ 1 & 0 & 0 & 0 \\ 1 & 0 & 0 & 1 \\ 4 & 0 & 9 & 3 \\ 0 & 0 & 0 & 0 \\ 35 & 3 & 0 & 0 \\ 0 & 1 & 2 & 1 \\ 2 & 0 & 5 & 1 \\ 20 & 19 & 16 & 12 \\ 6 & 1 & 13 & 1 \\ 1 & 0 & 0 & 0 \\ 2 & 0 & 0 & 0 \\ 0 & 0 & 0 & 0 \\ 5 & 4 & 6 & 1 \\ 0 & 0 & 0 & 1 \\ 20 & 14 & 12 & 11 \\ 1 & 0 & 0 & 1 \\ 3 & 0 & 1 & 0 \\ 9 & 1 & 2 & 1 \\ 0 & 0 & 0 & 0 \\ 13 & 3 & 4 & 3 \\ 0 & 1 & 27 & 9 \\ 0 & 0 & 0 & 0 \\ 0 & 0 & 2 & 1 \\ 36 & 32 & 71 & 60 \\ 0 & 0 & 3 & 0 \\ 81 & 31 & 98 & 85 \\ 0 & 0 & 0 & 1 \\ & & & \\ 0 & 0 & 0\end{array}$

\begin{tabular}{|c|c|}
\hline 0 & \\
\hline 0 & \\
\hline 0 & \\
\hline 115 & \\
\hline 24 & \\
\hline 0 & \\
\hline 0 & \\
\hline 0 & \\
\hline 5 & \\
\hline 0 & \\
\hline 0 & \\
\hline 18 & \\
\hline 0 & \\
\hline 26 & \\
\hline 0 & \\
\hline 0 & \\
\hline 0 & \\
\hline 1 & \\
\hline 0 & \\
\hline 0 & \\
\hline 14 & \\
\hline 0 & \\
\hline 0 & \\
\hline 0 & \\
\hline 0 & \\
\hline 0 & \\
\hline 0 & \\
\hline 0 & \\
\hline 1 & \\
\hline 21 & \\
\hline 0 & \\
\hline 39 & \\
\hline 0 & \\
\hline
\end{tabular}

LV

W, GL

O, GL

$\mathrm{O}, \mathrm{GL}$

W, O, GL

F, GL

GL, W

LV

LV

W, GL

W, GL

$\mathrm{O}, \mathrm{GL}$

W, GL

W, GL

W, LV

GL

O, GL

$\mathrm{O}, \mathrm{GL}$

W, GL

W

F, LV

$\mathrm{O}, \mathrm{LV}$

$\mathrm{O}, \mathrm{W}, \mathrm{GL}$

LV

W, LV

F, GL

GL

GL

F, GL

GL

F 
Lepthyphantes obscurus (Blackwall, 1841)

Lepthyphantes pallidus (O.P.-Cambridge, 1871)

Lepthyphantes tenebricola (Wider, 1834)

Lepthyphantes tenuis (Blackwall, 1852)

Lepthyphantes zimmermanni (Bertkau, 1890)

Leptorhoptrum robustum (Westring, 1851)

Lophomma punctatum (Blackwall, 1841)

Maro minutus (O.P.-Cambridge, 1906)

Maro sublestus (Falconer, 1915)

Maso sundervalli (Westring, 1851)

Meioneta beata (O.P.-Cambridge, 1906)

Meioneta mollis (O.P.-Cambridge, 1871)

Meioneta saxatilis (Blackwall, 1844)

Meta mengei (Blackwall, 1869)

Meta merianae (Scopli, 1763)

Meta segmentata (Clerck, 1757)

Metopobactrus prominulus (O.P.-Cambridge, 1872)

Micrargus herbigradus (Blackwall, 1854)

Micrargus subaequalis (Westring, 1851)

Microlinyphia pusilla (Sundevall, 1830)

Microneta viaria (Blackwall, 1841)

Milleriana inerrans (O.P.-Cambridge, 1885)

Minyriolus pusillus (Wider, 1834)

Monocephalus fuscipes (Blackwall, 1836)

Neon reticulatus (Blackwall, 1853)

Nereine clathrata (Sundevall, 1830)

Neriene Montana (Clerck, 1757)

Neriene peltata (Wider, 1834)

Nigma puella (Simon, 1870)

Oedothorax fuscus (Blackwall, 1834)

Oedothorax gibbosus (Blackwall, 1841)

Oedothorax retusus (Blackwall, 1851)

Oxyptila trux (Blackwall, 1846)

LV

W

LV

-

GL

LV

F, GL

GL

F, GL

LV

F, LV

LV

LV

$\mathrm{O}, \mathrm{W}, \mathrm{GL}$

$\mathrm{O}, \mathrm{W}, \mathrm{GL}$

$\mathrm{O}, \mathrm{GL}$

LV 
Pachygnatha clercki (Sundevall, 1823)

Pachygnatha degeeri (Sundevall, 1830)

Pardosa agricola (Thorell, 1856)

Pardosa amentata (Clerck, 1757)

Pardosa nigriceps (Thorell, 1856)

Pardosa palustris (Linnaeus, 1758)

Pardosa pullata (Clerck, 1757)

Pelecopsis mengei (Simon, 1884)

Pelecopsis nemoralis (Blackwall, 1841)

Pelecopsis parallela (Wider, 1834)

Pepnocranium ludicrum (O.P.-Cambridge, 1861)

Pholcomma gibbum (Westring, 1851)

Pirata hygrophilus (Thorell, 1872)

Pirata latitans (Blackwall, 1841)

Pirata piraticus (Clerck, 1757)

Pirata uliginosus (Thorell, 1856)

Pisaura mirabilis (Clerck, 1757)

Pocadicnemis juncea (Locket \& Millidge, 1853)

Pocadicnemis pumila (Blackwall, 1841)

Poeciloneta globosa (Blackwall, 1841)

Porrhomma egeria (Simon, 1884)

Porrhomma pygmaeum (Blackwall, 1834)

Robertus arundineti (O.P.-Cambridge, 1871)

Robertus lividus (Blackwall, 1836)

Robertus neglectus (O.P.-Cambridge, 1871)

Saaristoa abnormis (Blackwall, 1841)

Saaristoa firma (O.P.-Cambridge, 1905)

Saloca diceros (O.P.-Cambridge, 1871)

Satilatlas britteni (Jackson, 1913)

Savignya frontata (Blackwall, 1833)

Scotina gracilipes (Blackwall, 1859)

Segestria senoculata (Linnaeus, 1758)

Silometopus elegans (O.P.-Cambridge, 1872)

\begin{tabular}{|c|c|c|c|}
\hline 34 & 10 & 23 & 6 \\
\hline 526 & 33 & 29 & 6 \\
\hline 0 & 0 & 0 & 0 \\
\hline 12 & 49 & 0 & 1 \\
\hline 168 & 28 & 33 & 5 \\
\hline 4 & 0 & 0 & 0 \\
\hline 1628 & 188 & 230 & 67 \\
\hline 1 & 2 & 0 & 0 \\
\hline 0 & 0 & 0 & 0 \\
\hline 4 & 0 & 2 & 0 \\
\hline 23 & 10 & 21 & 2 \\
\hline 0 & 0 & 2 & 3 \\
\hline 19 & 1 & 8 & 3 \\
\hline 0 & 0 & 1 & 0 \\
\hline 472 & 108 & 75 & 28 \\
\hline 71 & 3 & 96 & 46 \\
\hline 0 & 0 & 0 & 0 \\
\hline 13 & 19 & 42 & 35 \\
\hline 111 & 54 & 269 & 274 \\
\hline 0 & 1 & 1 & 0 \\
\hline 0 & 0 & 0 & 0 \\
\hline 0 & 0 & 1 & 0 \\
\hline 3 & 2 & 2 & 4 \\
\hline 28 & 21 & 46 & 30 \\
\hline 0 & 0 & 0 & 0 \\
\hline 5 & 17 & 29 & 12 \\
\hline 0 & 1 & 1 & 0 \\
\hline 0 & 0 & 0 & 0 \\
\hline 79 & 1 & 0 & 0 \\
\hline 0 & 0 & 0 & 0 \\
\hline 1 & 0 & 0 & 0 \\
\hline 0 & 0 & 0 & 0 \\
\hline 749 & 491 & 214 & 108 \\
\hline
\end{tabular}

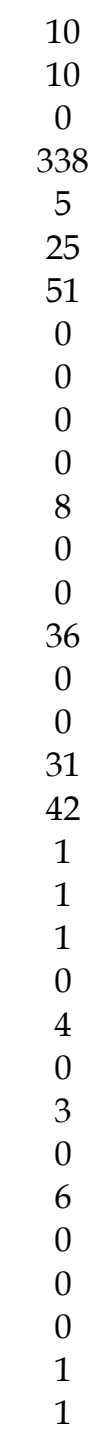

\begin{tabular}{|c|c|}
\hline 15 & 3 \\
\hline 24 & 1 \\
\hline 0 & 0 \\
\hline 404 & 132 \\
\hline 18 & 6 \\
\hline 17 & 2 \\
\hline 360 & 49 \\
\hline 1 & 0 \\
\hline 0 & 1 \\
\hline 0 & 0 \\
\hline 0 & 0 \\
\hline 1 & 5 \\
\hline 0 & 0 \\
\hline 0 & 0 \\
\hline 16 & 4 \\
\hline 0 & 0 \\
\hline 1 & 0 \\
\hline 90 & 84 \\
\hline 75 & 51 \\
\hline 1 & 1 \\
\hline 0 & 0 \\
\hline 0 & 1 \\
\hline 0 & 0 \\
\hline 23 & 6 \\
\hline 0 & 0 \\
\hline 8 & 8 \\
\hline 0 & 0 \\
\hline 0 & 6 \\
\hline 0 & 0 \\
\hline 0 & 0 \\
\hline 0 & 0 \\
\hline 0 & 4 \\
\hline 6 & 1 \\
\hline
\end{tabular}

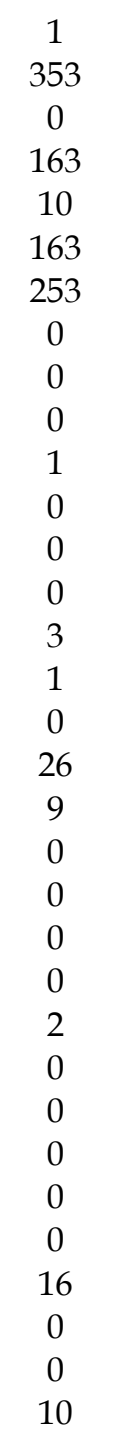

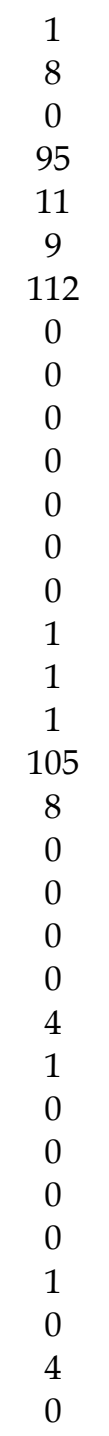

8
113
0
351
30
0
392
0
0
0
0
0
0
0
8
4
0
197
58
0
0
0
0
43
0
11
2
0
0
1
0
1
3

0
0
0
0
0
0
0
0
0
0
0
0
0
0
0

$\begin{array}{cl}4 & \text { W, LV } \\ 38 & \mathrm{LV} \\ 0 & \mathrm{O}, \mathrm{GL} \\ 83 & \mathrm{O}, \mathrm{W}, \mathrm{GL} \\ 22 & \mathrm{LV} \\ 0 & \mathrm{O}, \mathrm{GL} \\ 262 & \mathrm{O}, \mathrm{GL} \\ 0 & \mathrm{~W}, \mathrm{GL} \\ 0 & \mathrm{~F} \\ 0 & - \\ 0 & - \\ 2 & \mathrm{GL} \\ 0 & \mathrm{O}, \mathrm{W}, \mathrm{GL} \\ 0 & \mathrm{O}, \mathrm{W}, \mathrm{GL} \\ 3 & \mathrm{~W}, \mathrm{GL} \\ 0 & \mathrm{O}, \mathrm{GL} \\ 0 & \mathrm{LV} \\ 210 & \mathrm{O} \\ 10 & \mathrm{O} \\ 0 & \mathrm{O} \\ 0 & - \\ 0 & \mathrm{~W} \\ 0 & \mathrm{GL} \\ 34 & \mathrm{GL} \\ 0 & \mathrm{GL} \\ 2 & \mathrm{GL} \\ 1 & - \\ 0 & \mathrm{~W}, \mathrm{GL} \\ 0 & \mathrm{O}, \mathrm{W}, \mathrm{GL} \\ 0 & - \\ 0 & \mathrm{GL} \\ 1 & - \\ 2 & \mathrm{O}, \mathrm{W}, \mathrm{GL}\end{array}$


Tallusia experta (O.P.-Cambridge, 1871)

Tapinoba longidens (Wider, 1834)

Tapinocyba insecta (L. Koch, 1869)

Tapinocyba pallens (O.P.-Cambridge, 1872)

Taranucnus setosus (Simon, 1884)

Tetragnatha montana (Simon, 1874)

Textrix denticulata (Olivier, 1789)

Theonoe minutissima (O.P.-Cambridge, 1879)

Theridion bimaculatum (Linnaeus, 1767)

Theridion instabile (O.P.-Cambridge, 1870)

Theridion pallens (Blackwall, 1834)

Theridiosoma gemnosum (Koch, 1877)

Tibellus maritimus (Menge, 1875)

Tibellus oblongus (Walckenaer, 1802)

Tiso vegans (Blackwall, 1834)

Trichopterna thorelli (Westring, 1861)

Trochosa ruricola (De Geer, 1778)

Trochosa spinipalpis (O.P.-Cambridge, 1895)

Trochosa terricola (Thorell, 1836)

Troxochrus scabriculus (Westring, 1851)

Walckenaeria acuminata (Blackwall,1833)

Walckenaeria antica (Wider, 1834)

Walckenaeria atrobtibialis (O. P.-Cambridge, 1878)

Walckenaeria clavicornis (Emerton, 1882)

Walckenaeria cuspidata (Blackwall, 1833)

Walckenaeria dysderoides (Wider, 1843)

Walckenaeria kochi (O. P.- Cambridge, 1872)

Walckenaeria nodosa (O.P.-Cambridge, 1873)

Walckenaeria nudipalpis (Westring, 1851)

Walckenaeria unicornis (O.P.-Cambridge, 1861)

Walckenaeria vigilax (Blackwall, 1851)

Xysticus cristatus (Clerck, 1757)

Xysticus erraticus (Blackwall, 1834)

$\begin{array}{cccc}0 & 1 & 0 & 0 \\ 1 & 0 & 0 & 0 \\ 0 & 0 & 0 & 0 \\ 2 & 0 & 0 & 2 \\ 1 & 0 & 16 & 11 \\ 0 & 0 & 0 & 0 \\ 0 & 0 & 0 & 0 \\ 0 & 1 & 6 & 4 \\ 1 & 0 & 3 & 2 \\ 2 & 0 & 0 & 0 \\ 0 & 0 & 1 & 0 \\ 0 & 0 & 0 & 0 \\ 1 & 1 & 0 & 0 \\ 2 & 0 & 1 & 0 \\ 37 & 47 & 1 & 0 \\ 165 & 1 & 2 & 0 \\ 8 & 0 & 0 & 0 \\ 6 & 0 & 1 & 0 \\ 69 & 43 & 39 & 9 \\ 0 & 1 & 0 & 0 \\ 5 & 12 & 6 & 7 \\ 7 & 3 & 1 & 0 \\ 33 & 8 & 58 & 11 \\ 1 & 0 & 0 & 0 \\ 8 & 2 & 3 & 6 \\ 0 & 1 & 0 & 0 \\ 0 & 0 & 0 & 1 \\ 2 & 1 & 0 & 0 \\ 8 & 1 & 8 & 1 \\ 3 & 4 & 1 & 2 \\ 89 & 52 & 10 & 9 \\ 12 & 3 & 0 & 0 \\ 1 & 0 & 0 & 0 \\ & & & \\ 1 & & 0\end{array}$

$\begin{array}{cc}7 & 1 \\ 0 & 0 \\ 1 & 0 \\ 0 & 0 \\ 7 & 2 \\ 0 & 1 \\ 0 & 1 \\ 0 & 0 \\ 0 & 0 \\ 0 & 1 \\ 0 & 0 \\ 0 & 0 \\ 0 & 0 \\ 0 & 0 \\ 1 & 0 \\ 0 & 0 \\ 0 & 1 \\ 59 & 16 \\ 32 & 3 \\ 0 & 0 \\ 6 & 4 \\ 0 & 0 \\ 0 & 0 \\ 0 & 0 \\ 2 & 4 \\ 0 & 0 \\ 0 & 0 \\ 0 & 0 \\ 6 & 1 \\ 2 & 9 \\ 42 & 16 \\ 16 & 2 \\ 0 & 0 \\ & 0 \\ 0 \\ 0 \\ 0 \\ 0 \\ 0 \\ 0 \\ 0 \\ 0\end{array}$

F, GL

W, LV

LV

GL

$\mathrm{LV}$

$\mathrm{LV}$

W, LV

LV

LV

GL

W, GL

GL

W, GL

GL

D, G

GL

GL

O, W, GL

GL

GL

$\mathrm{O}, \mathrm{W}, \mathrm{GL}$

W

GL

W, GL

$\mathrm{O}$ 
Xysticus ulmi (Hahn, 1831)

Zelotes latrielli (Simon, 1878)

Zelotes lutetianus (L. Koch, 1866)

Zora spinimana (Sundevall, 1833)

Immature

Total Individuals

\begin{tabular}{cccccc} 
& 0 & 0 & 0 & 1 & 0 \\
& 2 & 0 & 2 & 0 & 0 \\
& 1 & 0 & 0 & 0 & 0 \\
& 7 & 0 & 9 & 8 & 1 \\
Total Individuals & 612 & 180 & 598 & 328 & 308 \\
& 6942 & 2246 & 3204 & 1958 & 4552 \\
\hline
\end{tabular}

0
0
0
0
225
2107

$\begin{array}{cc}0 & 0 \\ 0 & 0 \\ 0 & 0 \\ 0 & 0 \\ 133 & 268 \\ 1443 & 3718\end{array}$

0
0
0
1
218
2641

0

0

0

108

1496
$\mathrm{O}, \mathrm{W}, \mathrm{LV}$

$\mathrm{O}, \mathrm{GL}$

$\mathrm{O}, \mathrm{GL}$

GL 